Meta

Journal des traducteurs

Translators' Journal

\title{
Invention and "Invention"
}

\section{Avan Manning}

Volume 23, numéro 4, décembre 1978

URI : https://id.erudit.org/iderudit/003550ar

DOI : https://doi.org/10.7202/003550ar

Aller au sommaire du numéro

Éditeur(s)

Les Presses de l'Université de Montréal

ISSN

0026-0452 (imprimé)

1492-1421 (numérique)

Découvrir la revue

Citer cet article

Manning, A. (1978). Invention and "Invention". Meta, 23(4), 314-315.

https://doi.org/10.7202/003550ar

Ce document est protégé par la loi sur le droit d'auteur. L'utilisation des services d'Érudit (y compris la reproduction) est assujettie à sa politique d'utilisation que vous pouvez consulter en ligne.

https://apropos.erudit.org/fr/usagers/politique-dutilisation/
Cet article est diffusé et préservé par Érudit.

Érudit est un consortium interuniversitaire sans but lucratif composé de l'Université de Montréal, l'Université Laval et l'Université du Québec à Montréal. Il a pour mission la promotion et la valorisation de la recherche. https://www.erudit.org/fr/ 


\section{INVENTION AND «INVENTION"}

What the French critic, Charles du Bos, once defined as the goal of literary criticism also summarizes the first step in translation:

la voie de la critique idéale étant la voie même de la production, mais parcourue en sens inverse, le critique....(a)...pour point de départ le point d'arrivée du créateur, et pour point d'arrivée son point de départ ${ }^{1}$.

In other words, translation involves more than simply taking over where the original text leaves off. The author's "point d'arrivée " - or finished text - is the "langue de départ" of the translator whose role is to guide it to his own "langue d'arrivée ", which must be faithful to the author's "point de départ". Therefore, the translator must first penetrate the text, or read "between the lines " to grasp the author's true intentions. Once he has accomplished this, and, of course, isolated the stylistic features of the text, he is in a position to begin rendering the text. Translation - as every translator knows - is not a straightforward process. Pitfalls are numerous on a lexical as well as a syntactical level. One such member of this « fifth column " presented itself in the unusual use of the word invention by Gustave Lanson in the following passage:

Enfin, la forme grave et supérieure de notre intelligence, c'est l'esprit d'analyse, subtil et fort, et la logique aiguë et serrée: le don de représenter par une simplification lumineuse les éléments essentiels de la réalité, et celui de suivre à l'infini sans l'embrouiller ni le rompre jamais le fil des raisonnements abstraits; c'est le génie de l'invention psychologique et de la construction mathématique ${ }^{2}$.

The text suggest that invention connotes a vigorous analysis that leads to an uncovering of the salient aspects of the French mind. Moreover, some lines earlier Lanson had said: "Notre nation... tend naturellement à chercher surtout les relations et les manifestations du "moi »,... (chercher) une évidence pour avoir une certitude absolue." This substantiates the idea of invention being a "finding ", or, more accurately, «finding out $\%$.

In modern French, the meaning of invention is confined to some newly discovered

1. Charles du Bos, Journal, novembre 1917, in Extraits d'un Journal, 1908-1928, $2^{\mathrm{e}}$ éd., augm., Paris, Corrêa, 1931, vol. I, p. 189.

2. Gustave Lanson, Histoire de la littérature française, Paris, Hachette, 1938, p. 8. 
device or contrivance - usually mechanical. Le Nouveau Petit Larousse (1959 edition) defines invention first and foremost as «faculté, action d'inventer ", and the example given of the word's use is l'« invention du paratonnerre est due à Franklin ». Similarly, the verb inventer signifies "imaginer quelque chose de nouveau ". Words like "imaginer" and "faculté " might lead one to expect some emphasis on invention as a mental process. In fact, as the examples show, the mental aspects of invention tend to be left on one side. "L'invention du paratonnerre" is action not faculté. Le Petit Robert omits the word "faculté " from its primary definition of invention. Indeed, invention is used to refer to mental activity in French today, but then it takes on the highly pejorative implications of deceit and untruth. Invention is a "mensonge inventé pour tromper», inventer is synonymous with «supposer", "controuver ", "imaginer une chose qu'on donne comme reelle". Finally, there exists an archaic usage of invention in the phrase invention de la Sainte Croix which refers to the discovery - a physical finding - in the 4th century of the True Cross by Helena, the mother of Constantine - still a festival in the Catholic Church today. What has been said of invention - and inventer - in French can also be applied to the English «invention» (viz. Webster, Chambers, Compact Dictionary of Canadian English).

It is therefore quite clear that any notion of invention as a positive mental activity is absent from modern French and modern English. However, another archaic connotation is given under invention in le Petit Larousse illustré ( 1959 edition): " action de trouver les arguments et les usages dont on peut faire usage pour traiter un sujet ». Invention, then, also implies a search, a finding out. It is in this sense that Lanson is using the word in the expression l'«invention psychologique ». Turning to English, The Oxford Dictionary lists "invention" as an archaic term belonging to rhetoric, as "the action of finding out, discovery ".

To understand how invention and invention used to have this meaning of "discovery", it is worthwhile recalling the etymology of the word. "Invention " derives from Latin inventio, which in turn is formed of a prefix in $(=$ in) and a verb venir $(=$ to come). Thus «invention » meant a coming into, upon, either by accident or intentionally. When it was applied to oratory and rhetoric, it took on the meaning of a search for arguments or devices to be used.

In summary, according to Lanson the writer's art expressed as the highest graver form of the French mind consists in a gift to discover and describe the essential elements of Man's nature. In this respect, the writer is compared to a rhetorician searching for illustrations to support his idea. Linvention psychologique could be translated in English as "psychological invention"; however, this use of the word here would be ambiguous, since it could imply a "making up, imagining» rather than an analytical, objective exercise; «invention" as a rhetorical term is too archaic in modern English to be readily comprehensive in order not to betray the author's "point de départ", it is therefore better to translate it as "psychological discovery".

AVAN MANNING 